\title{
Population dynamics of Moina minuta Hansen (1899), Ceriodaphnia cornuta Sars (1886), and Diaphanosoma spinulosum Herbst (1967) (Crustacea: Branchiopoda) in different nutrients $(\mathrm{N}$ and $\mathrm{P})$ concentration ranges
}

\author{
Dinâmica populacional de Moina minuta Hansen (1899), Ceriodaphnia cornuta \\ Sars (1886) e Diaphanosoma spinulosum Herbst (1967) (Crustacea: Branchiopoda) \\ em diferentes faixas de concentração de nutrientes $(\mathrm{N}$ e $\mathrm{P})$
}

Ana Carolina Brito Vieira ${ }^{1}$, Ana Maria Alves Medeiros ${ }^{2}$,
Leonardo Leôncio Ribeiro ${ }^{2}$ and Maria Cristina Crispim ${ }^{1}$
${ }^{1}$ Laboratório de Ecologia Aquática, Departamento de Sistemática e Ecologia,
Universidade Federal da Paraíba - UFPB, Campus I, Cidade Universitária, CEP 58059-970, João Pessoa, PB, Brazil
e-mail: carolgnv@yahoo.com.br; ccrispim@dse.ufpb.br
² Programa de Pós-graduação em Ciências Biológicas-Zoologia, Universidade Federal da Paraíba - UFPB,
Campus I, Cidade Universitária, CEP 58059-970, João Pessoa, PB, Brazil
e-mail: ana.maria.bio@hotmail.com; ribeiro.l.l@hotmail.com

\begin{abstract}
Aim: Aquatic environments of semi-arid regions are subject to changes in water quality and volume due to short and irregular rain seasons. Consequently, zooplankton composition changes in association to fluctuations in the trophic degree. To comprehend these processes, this study analyzed the influence of nutrient concentrations $(\mathrm{N}$ and $\mathrm{P})$ on the population dynamics of three species of Cladocera - Moina minuta, Ceriodaphnia cornuta, and Diapahnosoma spinulosum - from the Taperoá II Dam, Paraíba, Brazil; Methods: Animals were experimentally submitted to different nutrient concentrations as a means to reproduce specific trophic conditions from natural environments. Zooplankton densities were evaluated once every three days, with food (i.e. algal cultures) being supplied in alternate days. To compare population growth, an ANOVA was performed, followed by Tukey's HSD post-hoc test; Results: The population growth of the three species differed significantly both among species and among treatments. Moina minuta populations showed higher growth rates under higher nutrient concentrations, whereas Ceriodaphnia cornuta growed more efficiently in intermediate concentrations, and Diaphanosoma spinulosum showed a better development in low nutrient concentrations; Conclusions: The results from the experimental approach, presented here, are similar to what is observed in the field, based on previous studies carried out in the Taperoá II Dam. Therefore, these results suggest that the hydrological cycle seems to be the major determinant of zooplankton population dynamics in aquatic semi-arid environments
\end{abstract}

Keywords: Cladocera, semi-arid, nutrient, trophic state.

Resumo: Objetivo: Os ambientes aquáticos de regióes semi-áridas sofrem alteraçóes na qualidade da água e no seu volume devido à irregularidade do período chuvoso. Consequentemente, o zooplâncton sofre alteraçóes em sua composiçáo com a evolução do estado trófico. Para a compreensão desse processo, este trabalho analisou experimentalmente a influência da concentraçáo de nutrientes ( $\mathrm{N}$ e P) sobre a dinâmica populacional de três espécies de cladóceros: Moina minuta, Ceriodaphnia cornuta e Diaphanosoma spinulosum; Métodos: Os animais foram submetidos a diferentes concentrações de nutrientes $(\mathrm{N}$ e P), de modo a representar diferentes níveis tróficos. As suas densidades foram medidas a cada três dias, e alimentação feita com uma cultura plurialgal em dias alternados. Para a comparação do desenvolvimento das populaçóes, foi feito o teste ANOVA, seguido do teste de Tukey; Resultados: $\mathrm{O}$ crescimento populacional das três espécies diferiu significativamente tanto entre as espécies quanto entre os tratamentos. As populaçóes de Moina minuta obtiveram maior crescimento nas concentraçóes mais elevadas de nutrientes e Ceriodaphnia cornuta em concentraçóes intermediárias, enquanto Diaphanosoma spinulosum se desenvolveu melhor no tratamento com baixa concentraçáo de nutrientes; 
Conclusóes: Observa-se que, para as três espécies, o resultado obtido em laboratório é similar ao observado em campo, obtidos em estudos realizados anteriormente no local, e que o ciclo hidrológico parece ser o principal regulador da dinâmica desses organismos em ambientes aquáticos do semi-árido.

Palavras-chave: Cladóceros, semi-árido, nutrientes, estado trófico.

\section{Introduction}

Amongst the groups that comprise zooplankton communities, Cladocera is one of the most important and representative, due to its role in energy and matter transfer (Vakkilainen et al., 2004). These organisms show an intimate relationship to environmental conditions (Reid and Wood, 1976), their populations being strongly controlled by biotic factors, such as food availability and predation by fishes and larger invertebrates (Abrantes et al., 2006), and abiotic factors, such as $\mathrm{pH}$, temperature, and concentration of several important compounds such as oxygen, ammonia (Phlips et al., 1997).

Due to their ecological importance, sensitivity to environmental changes, and easy handling (Brancelj et al., 1997), experimental studies with cladocerans are widely spread, with several aspects of their life histories, such as nutrition, predation, competition, ecotoxicologic tests, as well as tolerance to changes in water quality, being documented (see Ringelberg, 1997).

Among experimental studies, the influence of nutrients concentration ( $\mathrm{N}$ and $\mathrm{P}$ ) and the overall trophic state on zooplankton community composition is amongst the most studied aspect, given its importance in elucidating the ecological mechanisms responsible for matter and energy transfer. Studies conducted by Vakkilainen et al. (2004) and Esteves and Sendacz (1988) showed an increase in the biomass of rotifers, protozoans and small cladocerans, with no influence on filter feeders, such as larger cladocerans and calanoid copepods. Similar observations were made by KozlowskySuzuki and Bozelli (2002) and Sterza et al. (2002).

In environments where trophic conditions change seasonally, understanding how this process affects the ecological succession is extremely important in order to understand the dynamics of these ecosystems. This is the case for aquatic environments in the northeastern semi-arid region of Brazil, including the ecologically important Taperoá II Dam, evaluated in the present study. At these particular environments, yearlong high temperatures $\left(25-30{ }^{\circ} \mathrm{C}\right)$ predominate, whereas rainfall is scarce $\left(400 \mathrm{~mm}\right.$ year $\left.^{-1}\right)$ and highly irregular (Barbosa et al., 2002). Due to these severe climatic conditions, a deficit in water balance is typical of the region, turning the majority of water bodies in these areas temporary. This large cyclical variation in water volume, highly dependent on adequate rainfall rates, affects water quality, which consequently prompts corresponding variations in trophic conditions of these environments (Perez-Martinez et al., 1991; Crispim and Watanabe, 2000).

Studies with cladoceran populations in semiarid environments of Paraiba state indicate a clear ecological succession among the three most common species, which is strongly dependent on the hydrological regime of the region. For example, during the rainy season, Moina minuta Hansen 1899 is the first species to colonize the environment, soon decreasing its density and being replaced by Ceriodaphnia cornuta Sars 1886 and Diaphanosoma spinulosum Herbst 1967 (Freitas and Crispim, 2005; Crispim et al., 2003; Crispim and Watanabe, 2001). Due to these aspects, variations in environmental conditions, caused by changes in hydrological regimes, should be critical for the dynamics of these species. Therefore, evaluating these relationships is of major importance to understand the factors responsible for the population dynamics of cladoceran species in semiarid aquatic environments.

\section{Material and Methods}

Subject species - M. minuta, C. cornuta, and D. spinulosum - were originally isolated from Taperoá II Dam, in Taperoá city, Paraiba state, Brazil. One single individual of each species was selected to produce replicated clones.

Individuals were submitted to three treatments, in order to reproduce a gradient of nutrients concentrations $\left(\mathrm{NH}_{3}, \mathrm{NO}_{2}, \mathrm{NO}_{3}\right.$, and $\left.\mathrm{PO}_{4}\right)$ from three general trophic degrees (oligotrophic, mesotrophic, and eutrophic), as periodically observed in the study area. Data provided by Project PELD - Caatinga/CNPq, which also integrates the present study, was used to estimate these trophic conditions. Concentration ranges employed here are shown in Table 1. For this purpose, stock solutions were prepared for each nutrient following 
Table 1. Concentration gradients adopted during experimental procedures in laboratory.

\begin{tabular}{|c|c|c|c|c|}
\hline $\begin{array}{c}\text { Nutrient/ } \\
\text { Trophic state }\end{array}$ & $\begin{array}{c}\text { Ammonia } \\
\left(\mathrm{ClNH}_{4} 1000 \mathrm{mg}^{-\mathrm{L}^{-1}}\right)\end{array}$ & $\begin{array}{c}\text { Nitrite } \\
\left(\mathrm{NaNO}_{2} 100 \mathrm{mg}^{-\mathrm{L}^{-1}}\right)\end{array}$ & $\begin{array}{c}\text { Nitrate } \\
\left(\mathrm{NaNO}_{3} 1000 \mathrm{mg} \cdot \mathrm{L}^{-1}\right)\end{array}$ & $\begin{array}{c}\text { Ortophosphate } \\
\left(\mathrm{K}_{2} \mathrm{PO}_{4} 1000 \mathrm{mg}^{-1} \mathrm{~L}^{-1}\right)\end{array}$ \\
\hline Oligotrophic & $20 \mu \mathrm{g} \cdot \mathrm{L}^{-1}$ & $10 \mu \mathrm{g} . \mathrm{L}^{-1}$ & $20 \mu \mathrm{g} \cdot \mathrm{L}^{-1}$ & $10 \mu \mathrm{g} \cdot \mathrm{L}^{-1}$ \\
\hline Mesotrophic & $100 \mu \mathrm{g} \cdot \mathrm{L}^{-1}$ & $50 \mu \mathrm{g} \cdot \mathrm{L}^{-1}$ & $100 \mu \mathrm{g} \cdot \mathrm{L}^{-1}$ & $50 \mu \mathrm{g} \cdot \mathrm{L}^{-1}$ \\
\hline Eutrophic & $1800 \mu \mathrm{g} \cdot \mathrm{L}^{-1}$ & $100 \mu g \cdot L^{-1}$ & $2000 \mu \mathrm{g} \cdot \mathrm{L}^{-1}$ & $500 \mu g \cdot L^{-1}$ \\
\hline
\end{tabular}

the procedures described in Standard Methods (Clesceri et al. 1998). For each treatment, the culture was prepared with $900 \mathrm{~mL}$ of water from Taperoá Dam, $25 \mathrm{~mL}$ of stock solution from each specific nutrient, for each proposed concentration value. Prior to these procedures, water was filtered and analyzed to evaluate its original nutrient content.

Ten neonates with about $22 \pm 2$ hours of life were added to the aquariums at the beginning of the experiment, and the abundance of populations was observed once every three days. The experiment was conducted in a laboratory with a controlled temperature of $25+1{ }^{\circ} \mathrm{C}$ and $12 \mathrm{~h} 30: 11 \mathrm{~h} 30$ (day:night) photoperiod, with animals being fed every two days. Cladocerans were fed $1,5 \times 10^{6}$ cells per $\mathrm{mL}$ of a mixed culture of chlorophyceaes (Scenedesmus, Chlorella, Kirchneriella), in Conway culture. The experiment lasted three weeks, with three replicates for each treatment. Population growth rate was calculated following (Equation 1):

$\mathrm{r}=\frac{\ln \mathrm{N}_{\mathrm{t}}-\ln \mathrm{N}_{0}}{\Delta \mathrm{t}}$

where $\mathrm{N}_{0}=$ initial density and $\mathrm{N}_{\mathrm{t}}=$ density after $\Delta \mathrm{t}$ (days), (Krebs, 1998).

To compare the population growth of each species in three different treatments one-way analyses of variance (ANOVA), followed by Tukey's HSD test were carried out.

\section{Results}

Positive growth rates were observed for all species at the three experimental treatments, but somewhat distinct patterns were observed (Figure 1). Significant differences in zooplankton density among species were observed on the oligotrophic (ANOVA; $\mathrm{F}_{2,6}=137.4 ; \mathrm{p}<0.001$ ), mesotrophic (ANOVA; $\mathrm{F}_{2,6}=28.6 ; \mathrm{p}<0.001$ ), and eutrophic $\left(\mathrm{F}_{2,6}=343.2 ; \mathrm{p}<0.001\right)$ treatments, during the $12^{\text {th }}$ day of experiment. Densities were significantly different among all species on the oligotrophic treatment (Tukey's HSD test, $\mathrm{p}<0.001$ in all cases), D. spinulosum (mean $=224$ individuals) showing significantly higher densities than $M$. minuta
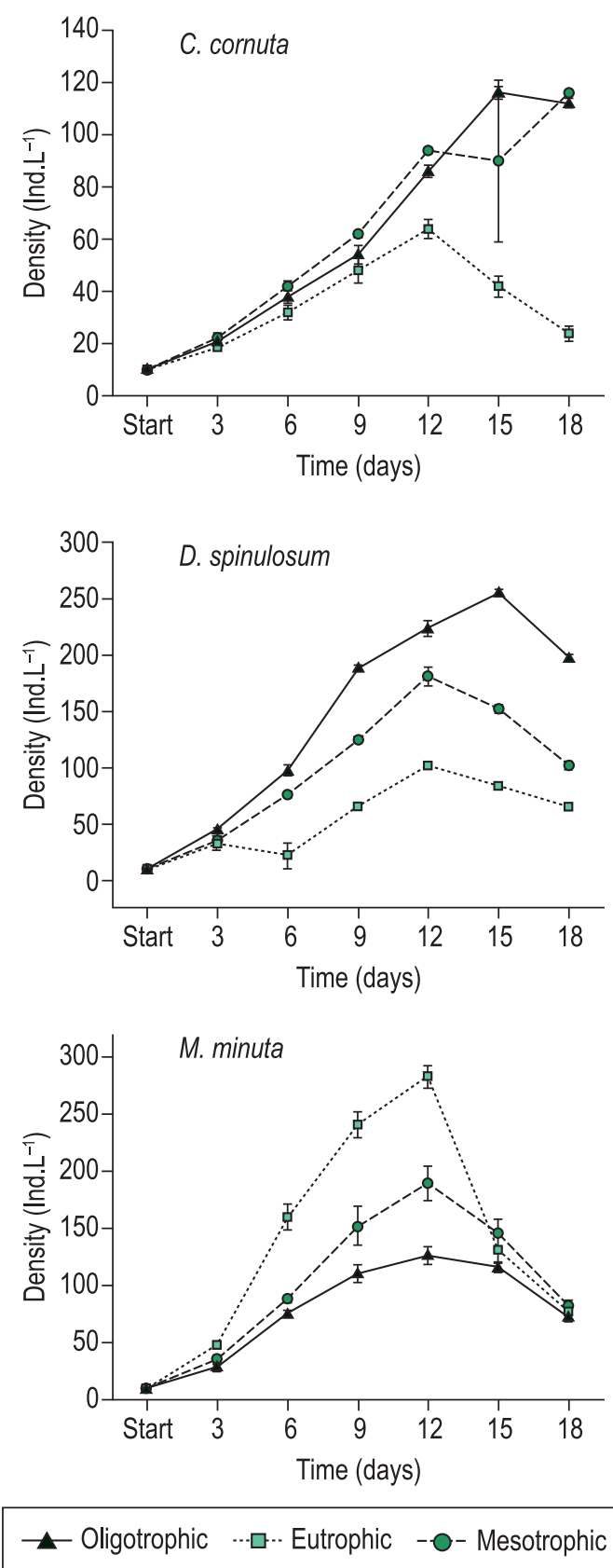

Figure 1. Mean \pm SE densities of three cladoceran species (Moina minuta, Ceriodaphnia cornuta and Diaphanosoma spinulosum) at three experimental treatments following a trophic gradient (oligotrophic, mesotrophic and eutrophic). 
$($ mean $=127)$, which, in turn, showed significantly higher values than $C$. cornuta $($ mean $=86)$. On the mesotrophic treatment, significant differences were observed between the densities of $M$. minuta (190) and C. cornuta (94) (Tukey's HSD test, $\mathrm{p}<0.01$ ), and between D. spinulosum (181.3) and C. cornuta (Tukey's HSD test, $\mathrm{p}<0.01$ ), $M$. minuta and D. spinulosum showing similar values (Tukey's HSD test, $\mathrm{p}>0.05$ ). On the eutrophic treatment, densities of the three species were significantly different (Tukey's HSD test, $\mathrm{p}<0.05$ in all cases), M. minuta (283) significantly showing higher values than D. spinulosum (102.7), which, in turn, was significantly higher than those of C. cornuta (64).

Throughout the experiment, growth rate differed significantly among the three species in the oligotrophic (ANOVA; $\mathrm{F}_{2,6}=10.7 ; \mathrm{p}<0.05$ ), mesotrophic (ANOVA; $\mathrm{F}_{2,6}=8.5 ; \mathrm{p}<0.05$ ), and eutrophic (ANOVA; $\mathrm{F}_{2,6}=6.7 ; \mathrm{p}<0.05$ ) treatments (Figure 2). On the oligotrophic treatment, significant differences were observed between the growth rate of $M$. minuta and $C$. cornuta (Tukey's HSD test, $\mathrm{p}<0.05)$ and $D$. spinulosum and C. cornuta (Tukey's HSD test, $\mathrm{p}<0.05$ ), M. minuta and $D$. spinulosum showing no significant differences (Tukey's HSD test, $\mathrm{p}>0.05$ ). On the mesotrophic treatment, growth rate was significantly different between $M$. minuta and C. cornuta (Tukey's HSD test, $\mathrm{p}<0.05$ ), but neither between $M$. minuta and D. spinulosum (Tukey's HSD test, $\mathrm{p}>0.05$ ), nor D. spinulosum and C. cornuta (Tukey's HSD test, $\mathrm{p}>0.05)$. On the eutrophic treatment, growth rate was only significantly different between M. minuta and D. spinulosum (Tukey's HSD test, $\mathrm{p}<0.05$ ), but were similar between $M$. minuta and $C$. cornuta (Tukey's HSD test, $\mathrm{p}>0.05$ ), and between $D$. spinulosum and C. cornuta (Tukey's HSD test, $\mathrm{p}>0.05)$.

\section{Discussion}

The subject species of the present study are not only the three most common cladoceran species of semi-arid dams in Paraiba state, but are also the most representative in tropical water bodies (Sarma et al., 2004; Dumont, 1994; Shrivastava et al., 1999). Moina minuta populations showed, in general, a faster growth rate and reached higher densities than populations of Ceriodaphnia cornuta and Diaphanosoma spinulosum. However, we observed that the population of the former species declined faster than those of the latter. Mangas-Ramírez et al. (2002) also observed a similar difference studying cultures of related Moina species.
These results support field observations from the Taperoá II Dam, which suggest that $M$. minuta is the first species to colonize the environment. Typically, this species shows a somewhat fast increase
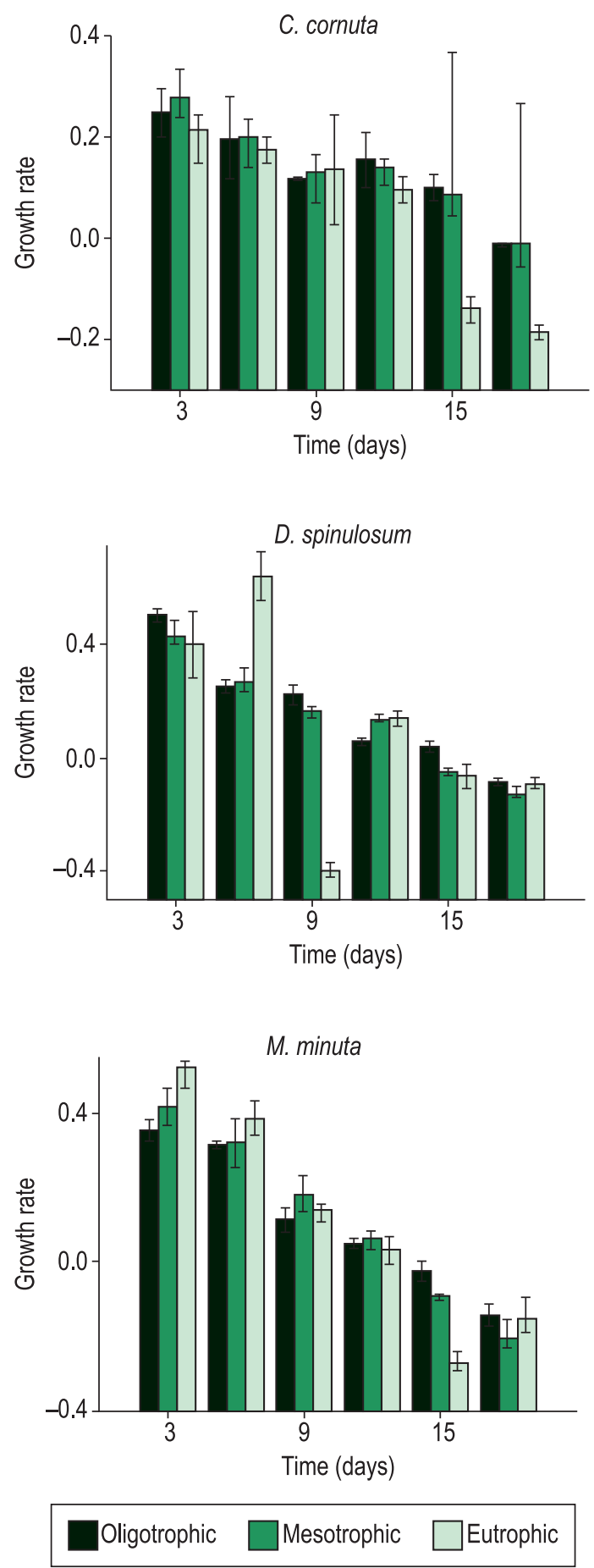

Figure 2. Mean $\pm \mathrm{SE}$ growth rates of three cladoceran species (Moina minuta, Ceriodaphnia cornuta and Diaphanosoma spinulosum) at three experimental treatments following a trophic gradient (oligotrophic, mesotrophic and eutrophic). 
in population density, which is followed by a corresponding decrease until it virtually disappears from the water column.

Population growth of M. minuta was positively influenced by higher nutrient concentrations. Nevertheless, it was also under these higher concentrations that population declines were more pronounced, whereas lower nutrient concentrations resulted in moderate mortality curves. Benider et al. (2002), in a similar experiment with Moina macrocopa, observed the same rapid development when cultures were submitted to high nutrients concentrations. This rapid increase in zooplankton density is easily explained by a trophic cascade effect, given that higher filtration rates are observed where algal biomass is larger due to an increased availability of nutrients from external sources (Jana and Pal, 1985; Bonou et al., 1991). This should also be the case for $M$. minuta in the present study.

Nandini and Sarma (2003) observed a higher population growth of $M$. macrocopa under higher concentration of algae than $C$. dubia, which showed higher growth under lower concentrations of algae. These authors associated these findings to the rapid life cycle of Moina (which seems to be an attribute of the genus). As a consequence, these species require a larger amount of food, for example, when compared to species of Ceriodaphnia (Nandini and Sarma, 2003). Sipaúba-Tavares and Bachion (2002) found similar results studying Moina micrura and Diaphanosoma birgei, where they observed a higher food requirement for the former species.

At Taperoá Dam, despite typical lower algal densities during rainy seasons, productivity rates are higher (Barbosa et al., 2002), which may provide food in abundance for $M$. minuta.

C. cornuta showed lower densities under higher nutrients concentrations. Villalobos and González (2006), in their study on the biology of C. cornuta, claimed that this species shows optimal growth rates on waters with trophic conditions varying between mesotrophic and oligotrophic, and that chlorophyceaes, diatoms and detritus are their primary source of their food (Ferrão-Filho et al., 2003; González, 2004; Wylie and Currie, 1991).

Populations of $D$. spinulosum showed higher growth rates under lower concentration of nutrients. Shrivastava et al. (1999) observed similar results in an experiment with Diaphanosoma celebensis, which also showed the largest population growth under low food conditions. The same was observed by Crispim and Boavida (2002) in competition experiments involving three species of Cladocera.
These authors found that higher population growths of Diaphanosoma brachyurum were observed at manipulated samples with low food

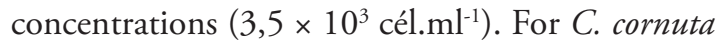
and $D$. spinulosum, the largest variations of growth rates as well as the highest decreases were observed under eutrophic conditions.

Boikova (2005) stated, from results of her experiment on D. brachyurum, that populations showed lowest growth rates and late post-embryonic development under conditions of high food levels. According to Wacker et al. (2001), Diaphanosoma is a genus of tropical cladocerans with low nutritional requirements and low tolerance to eutrophication (i.e. a stenotrophic species).

Within the population dynamics of the three species, as observed from our experimental data, a similar pattern to that of previous field investigations in the Taperoá II Dam was observed (Vieira et al., 2009). Populations of $M$. minuta reach peaks of densities under situations where mesotrophic and eutrophic conditions, and consequently, higher food availability, predominate in the dam, but soon after, population densities of this species start to decline. Further, this population decline is followed by an increase in the population growth of $D$. spinulosum and C. cornuta in the dam. This strategy of rapid growth, or "explosive growth" according to Romanovsky (1985), was reported by Benider et al. (2002), Ferrão-Filho et al. (2003), and Duncan (1989); their studies suggest that, after a period of population growth, these species invest almost all their energy on sexual reproduction, in order to guarantee an adequate stock of resting eggs in the sediment, with the consequential effect of continued species existence (Lynch, 1980; Rojas et al., 2001). This pattern is common at several aquatic ecosystems of semi-arid regions in Paraiba state, where, depending on environmental stability, M. minuta may produce different proportions (high or low) of ephippial females, soon after their density peaks (Crispim et al., 2003). However, it is noteworthy that as trophic levels increase, a change in phytoplankton diversity follows, thus turning typically abundant algal species into rare species. As a consequence, this change in phytoplankton diversity is usually followed by a corresponding change in zooplankton composition, particularly due to the fact that highly selective zooplankton predators, such as cladocerans, are most affected (Pace, 1986; Esteves and Sendacz, 1988; Sarma et al., 2003). 
Regarding C. cornuta populations, this species shows a peak of density in the dam at prevailing oligotrophic to mesotrophic conditions, and this observation is supported by our experimental results. Similar observations were made by FerrãoFilho et al. (2005) and Conde-Porcuna et al. (2002), which stated that Ceriodaphnia species grow better under moderate trophic conditions. Romanovsky (1985) ranked Ceriodaphnia as a genus of "low growth", but with great tolerance to starvation, toxic algae and mineral limitation of $\mathrm{N}$ and $\mathrm{P}$. With regards to $D$. spinulosum populations, observations of the present experimental study were also similar to a previous study conducted at the dam (Vieira et al., 2009). D. spinulosum showed higher population densities when the dam was under oligotrophic conditions. Other studies conducted with congeners as subject species showed that the highest densities were recorded under oligotrophic conditions (Neves et al., 2003; Gulati et al., 1990, 1990; Mengestou and Fernando, 1991). Boikova (2005), in her study on $D$. brachyurum, noted that populations thrived best at low trophic conditions, showing density variations under higher trophic conditions, as well as changes in embryonic and post-embryonic development. Similar results were also found by Malhotra and Langer (1993).

Based on the aforementioned considerations, it becomes clear that the effects of nutrients concentrations on cladoceran populations are of an indirect nature, formerly influencing their food supply through an algal dynamics and consequently, the overall zooplankton community, via trophic cascades. Some of the compounds studied, such as ammonia and nitrite, have known toxic effects on organisms, (Esteves, 1998). However, concentrations used during the experiment did not reach harmful levels to organismal development and, therefore, had no apparent negative effect on individual-level fitness. Similar results were observed in studies carried out by Elser et al. (1988), Sterza et al. (2002), Benider et al. (2002), Makino et al. (2002) and Kozlowsky-Suzuki and Bozelli (2002).

Environments subject to a unidirectional increase in nutrients concentrations show a permanent shift in phytoplankton community composition, which tends to be replaced by communities with low richness and high dominance of few species, particularly cyanobacteria and euglenids (i.e. decreased diversity) (Smith et al., 1999; Sterza et al., 2002; Boersma and Vijverberg, 1996). Furthermore, during these shifts, microzooplankton species (rotifers and protozoans) tend to substitute or become more abundant than macrozooplankton ones (cladocerans and calanoid copepods). Nevertheless, when the nature of this process is cyclical, as observed at Caatinga environments, a return to the former, and preferred conditions regarding community development occurs, this being a common annual cycle triggered by the periodic hydrological regimes and made available by ephippial eggs deposited on the sediments (Crispim and Watanabe, 2000).

The somewhat large cyclical fluctuations, typical of semi-arid environments, enable the so-called "ideal" conditions for the development of particular species from different periods, given the changes on the enrironmental quality, which is directly influenced by the hydrological cycle. In other words, there is a cyclical ecological succession, or a cyclical temporal succession which is dependent upon changes in environmental quality. According to Mageed and Heikal (2006), a change in the water's chemical composition, and consequently its trophic state, is the main factor responsible for the seasonal fluctuations of zooplankton composition at tropical environments, as opposed to what is observed at temperate water bodies, in which temperature is, by far, the most important determinant (Sarma et al., 2005).

Particularly for cladoceran populations, the influence of water quality is more pronounced, given the fact that these animals show a lower tolerance to environmental fluctuations than do other zooplankton groups (Goldman et al., 1979; Esteves and Sendacz, 1988; Elser et al., 1988; Conde-Porcuna et al., 2002; Kappes and Sinsch, 2005). Therefore, this explains, at least partially, the low densities of this group when compared to others recorded in similar dams (Crispim and Watanabe, 2003; Vieira et al., 2009).

Based on the results shown in the present study (laboratory analyses), along with historical field analyses, we state that the three subject species are important indicators of trophic conditions at the dam, providing an indirect, albeit consistent, measure of its water quality. These relationships explain the sequence of species replacement observed in dams of semi-arid regions in Paraiba state, where, during the beginning of the rainy season, $M$. minuta is the first species to colonize the environment, followed by C. cornuta and, finally, D. spinulosum. In fact, soon after the beginning of the first rains, an increase in phytoplankton primary productivity takes place (Dantas, 2009), due to 
the dilution of stressful conditions (such as the decrease in $\mathrm{pH}$ and electrical conductivity values, which are typically high during the dry season and a limiting factor for some species) coupled with an input of nitrogen compounds caused by water discharge and sediment lixiviation (Crispim et al., 2003). As a consequence, this increase in algal biomass, will provide food in abundance to the overall heterotrophic aquatic community. The particularly noteworthy positive effects of increased primary productivity on the density of $M$. minuta, given that this species reached higher densities than the other evaluated species (Crispim et al., 2003), comes about from its strong herbivorous pressure. The resulting decrease (or stability) in food levels, favor the presence of C. cornuta and D. spinulosum. These latter species, along with calanoid Copepoda species, are more abundant around two to three months subsequent to the beginning of the rainy season at these ecosystems.

\section{Acknowledgements}

We would like to acknowledge $\mathrm{CNPq}$ for funding this research and granting Ana Carolina with a MSc. scholarship, and also to Professor Douglas Fregolente (Universidade Federal de Campina Grande), for his help on the manuscript. This project is part of PELD Caatinga: Structure and Functioning.

\section{References}

ABRANTES, N., ANTUNES, SC., PEREIRA, MJ. and GONÇALVES, F. 2006. Seasonal succession of cladocerans and phytoplankton and their interactions in shallow eutrophic lakes (Lake Vela, Portugal). Acta Oecologica, vol. 29, p. 54-56. http://dx.doi. org/10.1016/j.actao.2005.07.006

BARBOSA, JEL., BORDINI, JA. and WATANABE, T. 2002. Interferência de alteraçōes climáticas globais no funcionamento de um açude do trópico semi-árido paraibano. São Carlos: EdUfscar.

BENIDER, A., TIFNOUTI, A. and POURRIOT, R. 2002. Growth of Moina macrocopa (Straus 1820) (Crustacea, Cladocera): influence of trophic conditions, population density and temperature. Hydrobiologia, vol. 468, p. 1-11. http://dx.doi. org/10.1023/A:1015214530485

BOERSMA, M. and VIJVERBERG, J. 1996. Food effect on life history traits and seasonal dynamics of Ceriodaphnia pulchella. Freshwater Biology, vol. 35, p. 25-34. http://dx.doi.org/10.1046/j.13652427.1996.00478.x

BOIKOVA, OS. 2005. Postembryonic development in Diaphanosoma brachyurum (Lievin, 1848)
(Crustacea: Ctenopoda: Sididae). Hydrobiologia, vol. 537, p. 7-14. http://dx.doi.org/10.1007/s10750004-1570-2

BONOU, CA., PAGANO, M.and SAINT-JEAN, L. 1991. Développemant et croissance en poids de Moina micrura et de Mesocyclops aginnus dans un milieu saumâtre tropical: les étangs de pisciculture de Layo (Côte d'Ivoire). Revue D'Hydrobiologie Tropicale, vol. 24, p. 287-303.

BRANCELJ, A., DEMEESTER, L. and SPAAK, P. 1997. Cladocera: The Biology of model Organisms. Dordrecht: Kluwer Academic Publishers.

CLESCERI, LS., GREENBERG AE. and EATON, AD.1998. Standard methods for the examination of water and wastewater. 20th ed. Baltimore: American Public Health Association.

CONDE-PORCÚNA, JM., RAMOS-RODRÍGUES, E. and PEREZ-MARTÍNEZ, C. 2002 Correlation between concentracions an zooplankton populations in a mesotrophic reservoir. Freshwater Biology, vol. 47, p. 1463-1473.

CRISPIM, MC. and BOAVIDA, MJ. 2002 Competição entre Diaphanosoma brachyurum, Daphnia hyalina e Daphnia parvula. Revista Nordestina de Biologia, vol. 16, p. 71-89.

CRISPIM, MC., DA PAZ, RJ. and WATANABE, T. 2003 Comparison of different Moina minuta populations dynamics ecloded from resting eggs in a semi-arid region in Brazil. Brazilian Journal of Ecology, vol. 5-6, p. 33-38.

CRISPIM, MC. and WATANABE, T. 2000. Ovos de resistência de rotíferos presentes em sedimetos secos de um açude no semi-árido paraibano. Acta Limnologica Brasiliensia, vol. 12, p. 89-94.

CRISPIM, MC. and WATANABE, T. 2001. What can dry reservoir sediments in a semi-arid region in Brazil tell us about cladocera? Hydrobiologia, vol. 442, p. 101105. http://dx.doi.org/10.1023/A:1017550603022

DANTAS, EW., ALMEIDA, VLS., BARBOSA, JEL., BITTENCOURT-OLIVEIRA, MC. and MOURA, AN. 2009. Efeito das variáveis abióticas e do fitoplâncton sobre a comunidade zooplanctônica em um reservatório do Nordeste brasileiro. Iheringia, Série Zoologica, vol. 99, p. 132-141.

DUMONT, HJ. 1994. On the diversity of the cladocera in the tropics. Hydrobiologia, vol. 272, p. 27-38. http://dx.doi.org/10.1007/BF00006510

DUNCAN, A. 1989. Food limitation and body size in the life cycles of planktonic rotifers and cladocerans. Hydrobiologia, vol. 186-187, p. 11-28. http://dx.doi. org/10.1007/BF00048891

ELSER, JJ., ELSER, MM., MACKAY, NA. and CARPENTE, SR. 1988. Zooplankton-mediated transitions between $\mathrm{N}$ - and P-limited algal growth. Limnology and Oceanography, vol. 33, p. 1-14. http:// dx.doi.org/10.4319/lo.1988.33.1.0001 
ESTEVES, FA. 1998. Fundamentos de Limnologia. Rio de Janeiro: Interciência FINEP.

ESTEVES, KE. and SENDACZ, S. 1988. Relações entre a biomassa do zooplâncton e o estado trófico de reservatórios de São Paulo. Acta Limnologica. Brasiliensia, vol. 2, p. 587-604.

FERRÁO-FILHO, A., ARCIFA, M. and FILETO, C. 2003. Resource limitation and food quality for cladocerans in a tropical Brazilian lake. Hydrobiologia, vol. 491, p. 201-210.

FERRÃO-FILHO, AS., DEMOTT, WR. and TESSIER, AJ. 2005. Responses of tropical cladocerans to a gradient of resource quality. Freshwater Biology, vol. 50, p. 954-964.

FREITAS, GTP. and CRISPIM, MC. 2005. Seasonal effects on zooplankton community in a temporary lagoon of northeast Brazil. Acta Limnologica Brasiliensia, vol. 17, p. 385-393.

GOLDMAN, CR., MORGAN, MD., THRELKELD, ST. and ANGELI, N. 1979. A population dynamics analysis of the cladoceran disappearance from Lake Tahoe, California-Nevada. Limnology and Oceanography, vol. 24, p. 289-297. http://dx.doi. org/10.4319/lo.1979.24.2.0289

GONZÁLEZ, E. 2004. Caracterización limnológica de los embalses Agua Fría (Estado Miranda) y Tierra Blanca (Estado Guárico). Caracas: Universidad Central de Venezuela. Proyecto S1- 98001361. Etapa II. Caracterización del embalse Tierra Blanca (Estado Guárico). Informe Técnico.

GULATI R, D., LAMMENS, EHRR., MEIJER, ML. and VAN DONK, E.1990. Biomanipulation: tools for water management: Developments in Hydrobiology. Belgium: Kluwer Publishing Association.

JANA, BB. and PAL, GP. 1985. The life history parameters of Moina micrura (Kurz) grown in different culturing media. Water research, vol. 19, p. 863-867. http://dx.doi.org/10.1016/00431354(85)90144-7

KAPPES, H. and SINSCH, U. 2005. Tolerance of Ceriodaphnia quadrangula and Diaphanosoma brachyurum (Crustacea: Cladocera) to experimental soft water acidification. Hydrobiologia, vol. 534, p. 109-115. http://dx.doi.org/10.1007/s10750004-1416-y

KOZLOWSKY-SUZUKI, B. and BOZELLI, RL. 2002. Experimental evidence of the effect of nutrient enrichment on the zooplankton in a brazilian coastal lagoon. Brazilian Journal of Biology, vol. 62, p. 835-846. http://dx.doi.org/10.1590/S151969842002000500013

KREBS, C. 1998. Ecological Methodology. 2th ed. Massachusetts: Addison Wesley Longman.

LYNCH, M. 1980. The evolution of cladoceran life histories. Quarterly Review of Biology, vol. 55, p. 23-42 http://dx.doi.org/10.1086/411614
MAGEED, AAA. and HEIKAL, MT. 2006. Factors affecting seasonal patterns in epilimnion zooplankton community in one of the largest man-made lakes in Africa (Lake Nasser, Egypt). Limnologica, vol. 36, p. 91-97.

MAKINO, W., URABE, J., ELSER, JJ. and YOSHMIZU, C. 2002. Evidence of phosphorus limited individual and population growth of Daphnia in a Canadian Shield lake. Oikos, vol. 96, p. 197-205. http://dx.doi. org/10.1034/j.1600-0706.2002.960201.x

MALHOTRA, YR. and LANGER, S. 1993. Nutritional and density-dependent responses of some cladocera. Aquaculture Research, vol. 24, p. 631-640. http:// dx.doi.org/10.1111/j.1365-2109.1993.tb00639.x

MANGAS-RAMIREZ, E., SARMA, SSS. and NANDINI, S. 2002. Combined effects of algal (Chlorella vulgaris) density and Ammonia concentracion on the population dynamics of Ceriodaphnia dubia and Moina macrocopa (Cladocera). Ecotoxicology and Environmental Safety, vol. 51, p. 216-222. http:// dx.doi.org/10.1006/eesa.2001.2128

MENGESTOU, SJG. and FERNANDO, CH. 1991. Biomass and production of the major dominant crustacean zooplankton in a tropical Rift Valley lake, Awasa, Ethiopia. Journal of Plankton Research, vol. 13, p. 831-851. http://dx.doi.org/10.1093/ plankt/13.4.831

NANDINI, S. and SARMA, SSS. 2003. Population growth of some genera of cladocerans (Cladocera) in relation to algal food (Chlorella vulgaris) levels. Hydrobiologia, vol. 491, p. 211-219. http://dx.doi. org/10.1023/A:1024410314313

NEVES, IF., ROCHA, O., ROCHE, KF. and PINTO, AA. 2003. Zooplankton community sctruture of two marginal lakes of the River Cuibá (MG) with analysis of Rotifera and Cladocera diversity. Brazilian Journal of Biology, vol. 63, p. 329-343.

PACE, ML. 1986. An empirical analysis of zooplankton community size structure across lake trophic gradients. Limnology and Oceanography, vol. 31, p. 45-55. http://dx.doi.org/10.4319/lo.1986.31.1.0045

PEREZ-MARTINEZ, C., MORALES-BAQUERO, R. and SANCHEZ-CASTILLO, P. 1991. The effect of the volume decreasing on the trophic status in four reservoirs from Southern Spain. Verhandlungen Internationale Vereinigung für theoretische und angewandte Limnologie, vol. 24, 1382-1385.

PHLIPS, EJ., CICHRA, M., HAVENS, L., HANLON, C., BADYLAK, S., RUETER, B., RANDALL, M. and HANSEN, P. 1997. Relationships between phytoplankton dynamics and the availability of light and nutrients in a shallow sub-tropical lake. Journal of Plankton Research, vol. 19, p. 319-342. http://dx.doi. org/10.1093/plankt/19.3.319 
REID, GK. and WOOD, RD. 1976. Ecology of Inland Waters and Estuaries. New York: D Van Nostrand Company.

RINGELBERG, J. 1997. Some suggestions for future cladoceran research. Hydrobiologia, vol.360, p. 291-294. http://dx.doi.org/10.1023/A:1003117419484

ROJAS, NET., MARINS, MA. and ROCHA, O. 2001. The effect of abiotic factors on the hatching of Moina micrura Kurz, 1874 (Crustacea: Cladocera) ephippial eggs. Brazilian Journal of Biology, vol. 61, p. 371-376.

ROMANOVSKY, YE. 1985. Food limitation and life history strategies in cladoceran crustaceans. In: Lampert, W. Food Limitation and the Structure of Zooplankton Communities). Archiv für Hydrobiologie, vol. 21, p. 363-372.

SARMA, SSS., DUMONT, HJ. and NANDINi, S. 2004. Interactions between the anomopod cladocerans Ceriodaphnia dubia, C. cornuta, Simocephalus vetulus and $S$. serrulatus, the aphanoneurid worm Aeolosoma sp., and the fish Skiffia lermae: predation or competition, or both? Hydrobiologia, vol. 526, p. 147-156. http://dx.doi.org/10.1023/ B:HYDR.0000041608.15608.93

SARMA, SSS., MANGAS-RAMÍREZ, E. and NANDINI, S. 2003. Effect of Ammonia toxicity on the competion among three species of Cladocerans (Crutacea: Cladocera). Ecotoxicology and environmental Safety, vol. 55, p. 227-235. http:// dx.doi.org/10.1016/S0147-6513(02)00120-3

SARMA, SSS., NANDINI, S. and GULATI, RD. 2005. Life history strategies of cladocerans: comparisons of tropical and temperate taxa. Hydrobiologia, vol. 542, p. 315-333. http://dx.doi.org/10.1007/s10750-0043247-2

SHRIVASTAVA, Y., MAHAMBRE, GG., ACHUTHANKUTTY, CT., FERNANDES, B., GOSWAMI, SC. and MADHUPRATAP, M. 1999. Parthenogenetic reproduction of Diaphanosoma celebensis (Crustacea: Cladocera). Effect of algae and algal density on survival, growth, life span and neonate production. Marine Biology, vol. 135, p. 663670. http://dx.doi.org/10.1007/s002270050667
SIPAÚBA-TAVARES, LH. and BACHION, MA. 2002. Populations growth an development of two specis of cladocerans Moina micrura and Diaphanosoma birgei in laboratory. Brazilian Journal of Biology, vol. 62, p. 701-711.

SMITH, VH., TILMAN, GD. and NEKOLA, JC. 1999. Eutrophication: impacts of excess nutrient inputs on freshwater, marine, and terrestrial ecosystems. Environmental Pollution, vol. 100, p. 179-196. http:// dx.doi.org/10.1016/S0269-7491(99)00091-3

STERZA, JM., SUZUKI, MS. and TAQUIL, A. 2002. Resposta do zooplâncton a adição e nutrientes inorgânicos ( $\mathrm{N}$ e P) em mesocosmos na Lagoa Açu, Campos dos Goytacazes/ São João da Barra, RJ. Acta Limnologica Brasiliensia, vol. 4, p. 87-94.

VAKKILAINEN, K., KAIRESALO, T., HIETALA, J., BALAYLA, DM., BÉCARES, E., VAN DE BUND, WJ., VAN DONK, E., FERNÁNDEZ-ALÁEZ, M., GYLLSTRÖM, M., HANSSON, L-A., MIRACLE, MR., MOSS, B., ROMO, S., RUEDA, J. and STEPHEN, D. 2004. Response of zooplankton to nutrient enrichment and fish in shallow lakes: a pan-European mesocosm experiment. Freshwater Biology, vol. 49, p. 1619-1632. http://dx.doi. org/10.1111/j.1365-2427.2004.01300.x

VIEIRA, ACB., RIBEIRO, LL., SANTOS, DPN. and CRISPIM, MC. 2009. Correlation between the zooplanktonic community and environmental variables in a reservoir from the Northeastern semi-arid. Acta Limnologica Brasiliensia, vol. 21, p. 349-358.

VILLALOBOS, MJ. and GONZÁLEZ, EJ. 2006. Estudios sobre la biología y ecología de Ceriodaphnia cornuta SARS: Una revisión. Interciência, vol. 31, p. 351-357.

WACKER, A., VON ELERT, E. and BERTNESS, MD. 2001. Polyunsaturated fatty acids: evidence for non-substitutable infochemical resources in Daphnia galeata. Ecology, vol. 82, p. 2507-2520.

WYLIE, JL. and CURRIE, DJ. 1991. The relative importance of bacteria and algae food sources for crustaceans zooplankton. Limnology and Oceanography, vol. 36, p. 708-728. http://dx.doi. org/10.4319/lo.1991.36.4.0708 